\title{
article
}

\section{Climate change? Archaeology and Anthropocene} póra Pétursdóttir

\begin{abstract}
As we pass into an age of the Anthropocene, archaeologists, as scholars of other disciplines, are driven to consider how this physical and ideological climate change affects our craft, or how archaeology can contribute with knowledge and insight of significance in a shifting world. Basing its arguments on research conducted on marine debris and drift beaches in northern Norway and Iceland, the aim of this article is to imagine what kind of alternative ways of doing and thinking archaeology the current climate is calling for. With reference to this material, which conspicuously manifests both obstacles and promises for an 'Anthropocene archaeology', the article will question the worth of some perspectives traditionally considered essential to our discipline, while simultaneously building on confidence in a sincerely archaeological imagination.
\end{abstract}

\section{Keywords}

Anthropocene; ontological turn; marine debris; plastic pollution; Eidsbukta, nonhuman agency; archaeology in/of the Anthropocene

\section{EXCERPT: FIELD REPORT}

Locality: Eidsbukta, Sværholt peninsula, Norway

Location: $70.96262^{\circ} \mathrm{N} 26.66342^{\circ} \mathrm{E}$

Date: 2 August 2015

Description: Section clearing in wrack zone of pebble beach

In order to get a better idea of the thickness or depth of the drift-matter assemblage on the beach, a section clearing was conducted at a chosen location. A suitable spot was found in the midst of the main wrack zone, where the accumulation and composition of material appeared pertinent. Section clearing was chosen above planar excavation, partly because the dynamic nature of the material made it nearly impossible to control four

*Department of Archaeology and Social Anthropology, UiT the Arctic University of Norway, Tromsø, Norway. Email: thora.petursdottir@uit.no. 


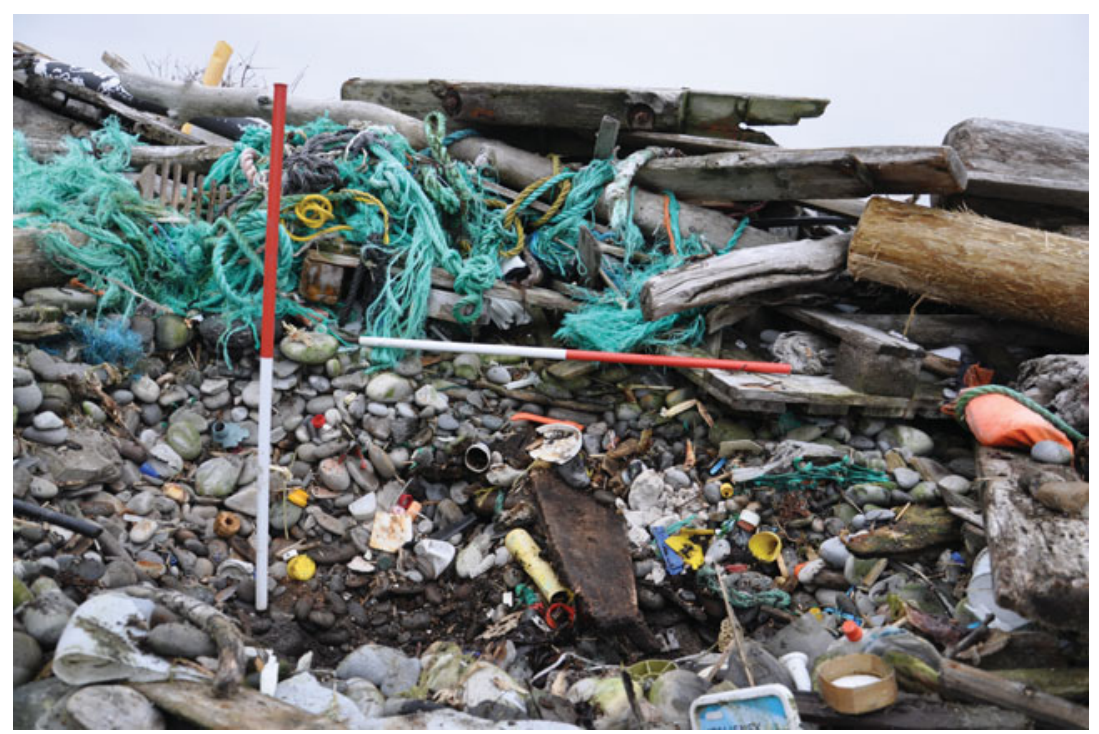

Figure 1 Cleared section in beach compound in Eidsbukta, Finnmark, Norway. Photo: Póra Pétursdóttir. (Colour online)

profiles, and partly because planar excavation was not expected to reveal any significant information beyond that afforded in a section.

The excavated section was east-facing, away from the shoreline. The spot was documented through photography (including pole photography) prior to, and regularly throughout, the excavation. The excavation was conducted using spade, trowel and hands and turned out to be very challenging. Several large logs had to be lifted/dragged out of the way, and the instability of the wrack assemblage and pebble beach sediments rendered it impossible to achieve a perfectly vertical section. For the same reasons the excavation had to be called to an end before it could be established that purely 'natural' sediments had been reached. The result thus was a slightly tapering section that, most likely, did not cut through the full depth of anthropogenic influence on the site - an outcome rather disconcerting to an archaeological orthodoxy.

Nevertheless, the section clearing revealed some interesting details of the beach compound. The final extent of the cleared section was approximately 1.3 metres in height and 1.5 metres in breadth (figure 1). Anthropogenic materials, mainly plastics of various kinds, were present in all levels of the section, with a clear decrease in size and amount from top to bottom. The material composition, and 'nature-culture ratio', was most even in the mid-section. The top layers were dominated by large-scale anthropogenic materials and wood, while the most fragmented anthropogenic materials the 'confetti' - in the lower levels appeared more thoroughly embraced by the beach sediment. This, however, is the image detectable by the naked eye, and the composition also of the lower layers is likely to be more complex upon closer examination. Telling of this were indications of leaching, manifested as an orange membrane detected on pebbles and in sediments of the lowest 
part. Here, samples were gathered for further inspection. No direct signs of conglomeration (plastiglomerate) were found in the section, whereas this had been identified elsewhere on the beach where materials had been affected by fire or other heat. Among objects identified in the section were two wooden pallets, several units of rope of different thicknesses and colours, branches, plastic tubes, plastic bottles and containers, plastic capsules of different colours, floats, pebbles, nylon fishing line, fishing net, pumice, crab shell, feathers, fish vertebrae, a black plastic comb, iron nails, an aluminium plate, pieces of rubber hose, timber logs and worked wood, bird bone, seaweed, sand and unidentified plastic pieces and confetti.

The results from the section clearing were neither extraordinary nor unanticipated. Rather, they show the very complex composition of the wrack zone, the deep and irreversible entanglement of 'natural' and 'cultural' materials, and the very vigorous processes - transformations, formations, associations - ongoing on the surface and in the depths of this chaotic compound. In addition, the very act of excavating and explicating this material - to render it archaeological, so to speak - also challenged my archaeo-logics in interesting and critical ways.

\section{Introduction}

I think, though, that the Anthropocene has administered - and will administer - a massive jolt to the imagination. In its unsettlement ... it opens up rather than foreclosing progressive thought.

Macfarlane 2016

The Anthropocene needs no introduction, one might claim. Quite literally, it has already introduced itself, announced its presence so distinctly that it appears impossible to dismiss; an urgent concern in geopolitical discourse and planning, but pressing no less in our everyday lives, manifested in sidewalk sewers, plastic bags and household garbage, recalled in the air we breathe, the water we drink and, not least, in the agony we feel growing inside us. 'Welcome to the Anthropocene', Elizabeth Kolbert (2014) greets us in her bluntly titled book The sixth extinction. But no need to despair, many also warrant. 'Some of the greatest accelerations in the life of our species-being have happened in moments of limit' (Wark 2015, xi). Hence, as marked already by the claimed authors of this novel naming, ahead of us lies 'an exciting, but also difficult and daunting task ... to guide mankind towards global, sustainable, environmental management' (Crutzen and Stoermer 2000, 18).

Extinction, stewardship, loss, sustainability, catastrophe, regeneration. This is the essence of the Anthropocenic dialogue as I see it; a melange of anguish, guilt and optimistic anticipation, where we are the root of the problem while the remedy is held in our essential exclusivity. 'We all know this civilization can't last. Let's make another' (Wark 2015, 225).

This article may be humming a similar tune. Focused on the field of archaeology, its aim is to imagine what kind of alternative ways of doing and thinking archaeology the current climate is calling for. The article is the outcome of work with marine debris and drift beaches in Iceland 
and northern Norway, and in particular fieldwork conducted in the wrack zones of Eidsbukta cove in sub-Arctic Norway. With reference to this material, which conspicuously manifests both obstacles and promises for an 'Anthropocene archaeology', the paper will question some perspectives traditionally considered essential to our discipline, but simultaneously build on confidence in a sincerely archaeological imagination.

Archaeology is the discipline of resilient things, of stuff that remains, which reflects an important affinity with this 'new' era. Despite its anthropocentric labelling, the Anthropocene, above all, bears witness to the longevity and volatility of things, big and small. A reminder not only of an exclusively buman footprint but also of an unruly heritage of material and morethan-human relations. As proposed by Robert Macfarlane (2016), its chief imaginative challenge 'is its inhuman organisation as an event'. It brings to the fore non-human agency and a-human, or post-human, relations. And when we claim that the Anthropocene is taking place, 'it does so across huge scales of space and vast spans of time ... Its energies are interactive, its properties are emergent and its structures withdrawn' (ibid.). A more-than-human climate that is truly unsettling and aggressive.

Archaeologists are already imagining how this climate change may alter archaeology, and how archaeology may contribute to its understanding and challenges. This article builds on these imaginations, but also questions some of the notions upheld. A discipline used to work with things and humanthing relations from the deep-time perspectives of culture history clearly has much to offer a more nuanced and critical understanding of the situation. At the same time, however, the unruly and more-than-human legacy that so candidly constitutes the empirical manifestations of the Anthropocene is, I argue, partly incompatible with, or not most eloquently grasped by, the ontoepistemology (cf. Barad 2007) of a culture-historical approach. Approaching this material through that convention, in other words, risks missing the mark of its belligerence and the challenges it places on archaeological practice and reasoning. This claim is what drives the imaginings of the current paper.

I will begin this quest by looking at how the Anthropocene is stirring archaeological thinking, and identify some trends in this scholarship. I will then move on to discuss how an object-oriented/more-than-human perspective may inform an alternative outset for an archaeology in/of the Anthropocene, with reference to the beach compounds in Eidsbukta (figure 2).

\section{Archaeology and Anthropocene}

Without ignoring the term's deeper pedigree (see e.g. Steffen et al. 2011; LeCain 2015, 5; Dalby 2016), the current notion of the Anthropocene was first introduced by chemist Paul J. Crutzen and ecologist Eugene F. Stoermer in the early 2000s. Their intent was to conceptualize the current global condition by introducing the Anthropocene as the next in a line of geological epochs or ages, succeeding or supplementing the Holocene (Crutzen and Stoermer 2000; Crutzen 2002). While the official ratification of the Anthropocene still awaits final verdict, including how to confine it chronologically (for discussion of the various controversies of this see e.g. Ruddiman 2003; 2005; Periman 2006; Zalasiewicz et al. 2011; Gibbard and Walker 2013; Rull 


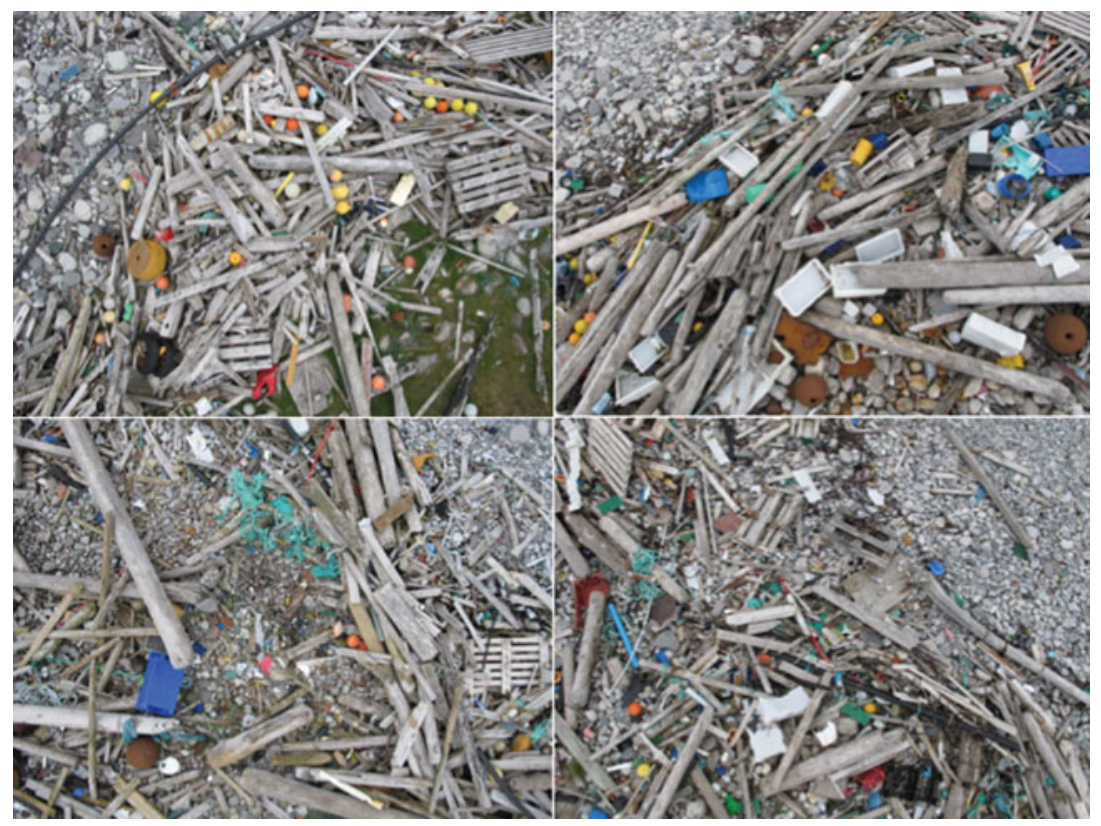

Figure 2 Pole photographs of drift-matter assemblages in main wrack zone, Eidsbukta. Photo: Póra Pétursdóttir. (Colour online)

2013; Edgeworth et al. 2015; LeCain 2015; Braje 2016), the concept's wide circulation and accumulated political significance imply that it is already here to stay - whether as an official age, epoch or neither. The Anthropocene, as stated by Simon Dalby $(2016,33)$, 'has become a key theme in contemporary speculations about the meaning of the present and the possibilities for the future'.

As initially introduced, the Anthropocene - sometimes referred to as 'the age of Man' - is meant to grasp the dramatic environmental consequences of the Industrial Revolution - our footprints - as these have evolved for the last 250 years, and intensely accelerated for the last half-century. This includes emission of greenhouse gases and global warming, melting ice caps, rising sea levels of increasingly acidified and littered oceans, soil contamination, habitat loss, species extinction, depletion of resources, geological invasion in the form of mining and landfill, the birth of industrial wastelands, and so on. We, it is argued, have become a major geo-environmental force, and without really intending to we have, as pictured by Ackerman (2014, 307), 'nearly emptied the world's pantry, left all the taps running, torn the furniture, strewn our old toys where they are becoming a menace, polluted and spilled and generally messed up our planetary home'.

This rather bleak narrative is telling of a considerable part of the discourse surrounding the Anthropocene today, where the human mistreatment of natural environments and notions such as pollution, loss and extinction are dominating. The opposite also exists and thrives, however, as represented by the more optimistic discourse of eco-pragmatists and geo-engineers, holding 
that the right kind of human planetary stewardship can secure a good, or at least a better, Anthropocene. As phrased by Erle Ellis (2012), 'we must not see the Anthropocene as a crisis, but as the beginning of a new geological epoch ripe with human-directed opportunity'.

While this is a brute generalization of a vast and diverse discourse, one can say that whether optimistic or pessimistic an often shared tendency of these predictions is a perspective that reinforces, rather than challenges, a conventional modernist distinction between culture and nature (for similar critique see e.g. Solli et al. 2011; Sullivan 2012; Clark and Hird 2014; LeCain 2015; Edgeworth 2016b; Haraway 2016; Yusoff 2016). 'Man' is threatening and $h$ is footprint polluting, while Earth is a victim, unknowing and blameless. Moreover, guilty of crimes against a nurturing nature, Man is now also responsible for fixing the problem. 'The Earth we have inherited from our ancestors', Ellis (2012) states, 'is now our responsibility. It is not natural limits that will determine whether this planet will sustain a robust measure of its evolutionary inheritance into the future'. Indeed, it is not without reason that voiced critique warns of the Anthropocene being precast by a neo-patriarchal treatise and 'under an all-too human fantasy of control theory' (Clarke 2014, 104; see also Margulis 1995).

This binary vision of man and nature, humanity and world, and the criticism thereof, is to a considerable extent telling also of the way the Anthropocene and current climate change have featured in archaeology. On the one hand, there are anxious voices concerned with the fate of archaeological heritage in a changing climate, the effect heritage loss will have on people's identity and sense of place, and the development of sufficient means of stewardship and archaeological resource management to secure salvation of sites and data (e.g. Chapman 2003; Howard et al. 2005; Colette 2007; Terrill 2008; Kaslegard 2010; Sabbioni, Brimblecombe and Cassar 2010; Howard 2013). On the other hand, there is a discourse more concerned with archaeology's expertise in studies of the human past and palaeoclimatic conditions, and with archaeology's role as one of many disciplines that can contribute with valuable insight and knowledge in response to current challenges and to the formation of the concept itself (e.g. Mitchell 2008; Guttmann-Bond 2010; Solli et al. 2011; Van de Noort 2011; Hudson et al. 2012; Rockman 2012; Sandweiss and Kelley 2012; Braje and Erlandson 2013; Davies and M'Mbogori 2013; Erlandson and Braje 2013; Edgeworth et al. 2014; Kintigh et al. 2014; Brewington et al. 2015; Crumley 2015; Lane 2015; Braje et al. 2016; Kluiving and Hamel 2016; Lafrenz Samuels 2016). It is this discourse that concerns me in the following.

There appears to be growing consensus, as stated by Matt Edgeworth (2014, 75), 'that archaeology has something substantial and important to contribute here - not only in terms of ideas and arguments ... but also in terms of a large body of evidence, in the form of the archaeological record'. This belief had been clearly stated also by Peter Mitchell $(2008,1096)$, who claims,

Few, if any, other disciplines can so successfully marshal the evidence of human activity and that of palaeoenvironmental change or, as a matter of 
course, join forces with geographers, climatologists and other environmental scientists to understand humanity within a framework that is at once historical and ecological, and thus able to critique Western narratives of environmental change. Without doubt, then, archaeologists can usefully contribute to academic, popular and political debates on the prediction and the management of climate change.

Mitchell even argues that this exclusive position also implies an 'archaeological responsibility' (ibid., 1096, original emphasis) to address these issues. In the same vein, Marcy Rockman $(2012,194)$ warns, 'Without the data, information, ideas, and interpretations that the field of archaeology can provide, there is much less of a chance of developing appropriate, workable, and durable means of addressing both mitigation and adaptation issues' (see also Guttmann-Bond 2010; Sandweiss and Kelley 2012; Crumley 2015).

As the argument goes, the 'human ecological footprint' is by tradition archaeology's major concern. The Anthropocene, in the form of 'artificial grounds' or the 'archaeosphere', as phrased by Edgeworth (2013; Edgeworth et al. 2015), has always been archaeology's geology - or, if you like, archaeology's climate. Archaeologists know where and what to look for, and they also know that our footprints may be traced much further back, much deeper in time, than is often considered. And this, not least, is seen as archaeology's most important asset; its experience with analysing the long-term, the 'deep-time perspective that stands to make significant contributions to understanding how humans have shaped the Earth' (Kintigh et al. 2014, 15), and thus its ability to 'enhance the socio-ecological resilience of communities and their adaptive capacity to climate change through the study of past pathways and adaptation' (Van de Noort 2011, 1039).

With few exceptions, the Anthropocene does not seem to stir a general rethinking of the archaeological project, but rather appears to reinforce traditional concerns and the importance of these for the current challenges. The understanding is that archaeology is already concerned with the longterm legacy of the Anthropocene, and that it only 'needs to extend that perspective, using the study of our ancestors to promote our own role as "good ancestors"' (Hudson et al. 2012, 324). To summarize, the claimed significance of the archaeological project may be captured in the four following (and overlapping) points:

1. Archaeology's long experience with nature-culture relations puts archaeology in a unique position to contribute to and challenge definitions of the Anthropocene, how it should be understood and how it has evolved in time.

2. The time-depth of archaeology's culture history provides valuable knowledge of collapse and adaptation, which enables us to learn from the past and prepare for the future.

3. Archaeologists are experts in stratigraphic reading of man-made surfaces and how these interact with, and can be distinguished from, natural strata. An archaeological method and deep-time perspective can therefore provide stratigraphic/physical markers, or 'golden spikes', that buttress 
or challenge notions of human impact, climate change and the relations between them.

4. For the same reason, archaeology's input is crucial also when it comes to dating the Anthropocene - when did it start, or can we in fact speak of a beginning?

These are all valid and important considerations. Surely, I do not suggest that they fully cover the various ways archaeologists are dealing with the Anthropocene, and some of these have, importantly, been strongly criticized. Paul Lane $(2015,11)$, for example, warns against 'making exaggerated claims that our backward-looking curiosity really can help us navigate the hazards of the Anthropocene'. Similarly, Alfredo González-Ruibal (2011) has questioned the call for deep-time perspectives, arguing that one has to consider the politics and ethics of stretching the Anthropocene both temporally and geographically (see also Crossland 2014). 'After all', he says, 'the Anthropocene did not start 2.5 million years ago with the first Homo, or 200,000 years ago, with the first sapiens, but about 250 years ago, when the systematic, large-scale, everexpanding predation against nature and society became a globally accepted form of political economy' (González-Ruibal 2011, 64). Hence, he argues, a short-term archaeology must not be ruled out.

Whether in favour of shorter- or deeper-time perspectives, what I find interesting in the many archaeological responses to the Anthropocene is the underlying pretext of a linear, stratified time, and of an absent past retrievable only through an archaeological exposure of deep culture history. And I wonder whether these approaches are the most applicable when it comes to matters of the current situation. Or whether some alternative but no less archaeological perspectives would be more helpful.

The very reason we speak of the Anthropocene is not that we have lost connection with the past but rather that we increasingly are unable to pretend that it's gone. The problem is not that things become buried deep in strata but that they endure, outlive us, and come back at us with a force we didn't realize they had. Thus, while I see the significance in a deep-time culturehistorical perspective, I also find it rather predictable. And what I miss in the archaeological discourse on the Anthropocene is 'the jolt to imagination' mentioned by Macfarlane; a concern for how it may affect our notion of time, the past and the archaeological record.

Interestingly, and hardly accidentally, at the same time as climate change and the notion of Anthropocene increasingly have become matters of concern, we have experienced a certain ontological 'climate change' in the humanities and social sciences: a turn to things, to materialities, where a darker, flatter and more entangled ecological thinking illuminates a more complex and nuanced perspective on earthly/planetary coexistence. The significance of this relation, which also underpins the arguments in this article, has been hinted at and elaborated by many (e.g. Morton 2010; 2016; Bryant and Joy 2014; Clarke 2014; Clark and Hird 2014; Latour 2011; 2014; Yusoff 2016), including archaeologists (Solli et al. 2011; Hudson 2014; Lane 2015; Randall 2016; Edgeworth 2016a). Especially in the context of archaeology and the Anthropocene, however, much remains unexplored. I will now briefly outline 
what I see as fundamental ontological considerations in this regard, before expounding this through a case study of material assemblages that are both telling of and challenging for notions of the Anthropocene.

\section{Ontology in a darkening world}

When preparing this paper, ${ }^{1}$ sitting by the kitchen table in my flat in Tromsø, with the radio humming in the background, a news story stirred me from my work. An announcement from LIGO - the Laser Interferometer GravitationalWave Observatory - confirmed the rumours that physicists had managed to detect 'ripples in space-time', and thus prove Einstein's century-old prediction of the existence of gravitational waves. The story, as later captured by Adrian Cho, writer at Science, went like this:

Long ago, deep in space, two massive black holes - the ultrastrong gravitational fields left behind by gigantic stars that collapsed to infinitesimal points - slowly drew together. The stellar ghosts spiralled ever closer, until, about 1.3 billion years ago, they whirled about each other at half the speed of light and finally merged. The collision sent a shudder through the universe: ripples in the fabric of space and time called gravitational waves. Five months ago, they washed past Earth. And, for the first time, physicists detected the waves, fulfilling a 4-decade quest and opening new eyes on the heavens. ${ }^{2}$

The almost romantically depicted collision of the two giants, or its belated but miraculous recording, has set off shudders and ripples also in the world of science. It has been declared that 'the direct detection of these ripples in spacetime not only confirm Einstein's famous theory of general relativity, they open our eyes to a previously "dark" universe'. ${ }^{3}$

Like many of us, I understand little of this - but enough, still, to find it mind-bogglingly fascinating. And though I do in fact apprehend Hawking's implication of the enlightenment of a previously dark universe, what this amazing achievement illuminates for me is rather more darkness than less. It is a reminder of the vastness, the infinity, of the universe. It brings to light the complexity, the strangeness, of time. And it decentres me, us humans, in the most radical and abrupt way. Hence, and without anything but admiration for this great work of science, for me this announcement, which for a moment stirred me from my work, first and foremost underscores what the universe yet withholds in darkness.

Maybe I was mainly struck by the analogy of this story to the stuff I was trying to get my head around. Waves mounting in a time and space so infinitely distant, and now uncaringly washing past Earth, are not without semblance to the incoming tides on a sub-Arctic drift beach. Also, struggling to make sense of the resulting beach assemblages appears to fold space and time, distance and proximity, in a way archaeological chronology rarely tolerates, but which may find semblance in these space-time ripples. In any case, I find this anecdote a good place to start because it also accidentally grasps what I identify as key issues of the current 'ontological turn', and which are of vital significance for an archaeology in/of the current climate. Grounding my stance are ideas introduced within object-oriented ontology (OOO), as 
proposed by Graham Harman (2010; 2016), Levi Bryant (2011; 2014), and others, and related theoretical writings, as those of Timothy Morton (2013; 2016) and Manuel DeLanda (2006). These strands invite a radically different perspective to our understanding of things and of non-human agency, and incite a critical view on matters of the Anthropocene.

Drawing on Graham Harman's recent exposition (2016), three issues are especially important for the following discussion, and each can be said to be recalled by the anecdote above: first is the importance of acknowledging the dark side of things - their integrity and own-ness. Opposing a tendency to reduce things' being to their relations and actions, each object, Harman argues, should be seen as a surplus exceeding its current affluence of doings and involvements. Like a 'sleeping giant' withholding the full wealth of its force (ibid., 7), this also means that there will always be a darkness involved in our encounter with the thing - a hidden excess integral to its being, and its potential futures.

A related, though different, notion is elaborated by Manuel DeLanda, who stresses the partial autonomy of individual parts in assembled action. It is important, DeLanda $(2006,10-11)$ argues, not to conflate a thing's characteristic properties with its capacities to interact with other entities. While the former may be known or rateable, the latter cannot be grasped or foretold at any given moment. That is, though dependent on its properties, a thing's capacity to act cannot be reduced to those, since its realization refers to interaction with (properties and capacities of) other entities (which in accordance are associated with yet other unforeseeable entanglements). Therefore, as capacities of becoming may partly be seen as afforded by the thing itself - already resting in its physique - its actual becoming is realized only through association with other things, which adds an aspect of volatility to its potential future. These references to things' unpredictability also bear semblance to Timothy Morton's (2013) notion of hyperobjects, which I will come back to in the discussion.

This relates directly to a second key issue: that things in themselves are not directly knowable or fully comprehensible (Harman 2016, 16-20). What this implies is, simply, that things escape our definitions and intellectual mastering, and cannot be reduced to our knowledge of them. Our knowledge/awareness does not at any time fully enlighten, equate to or substitute for their existence. Things exist, before, despite and after our knowledge thereof (just think of the merger of giants 1.3 billion light years away), and their actions and capacities are able to continuously surprise us. Thus, while 'things themselves' are available as matters of concern, reality to the object-oriented realist necessarily includes awareness of a surplus beyond any comprehension, causal interactions and knowable relations.

This notion also implicates care for the otherness and solitude of other beings, which brings me to the third issue evoked by the introductory anecdote, and which relates to ethics and politics. In common normative understanding, ethics and politics are exclusively matters of human associations and sociocultural relations. Here, the forceful interactions and consequent union of black holes a billion light years away is not a political affair. And predicting, and sincerely believing in the existence of, their vibrating 
gravitational force 100 years before you have the technical capacity to verify this is not an ethical posture. What an object-oriented ontology enables (and requires), however, is to imagine a very different type of politics and ethics, not reduced to human relations, involvement or even knowledge, but one that embraces the darkness beyond us. We might even call it a dark politics and dark ethics in harmony with Timothy Morton's dark ecology (2016).

Importantly, however, as argued by Levi Bryant in his Onto-cartography (2014), this is not a matter of advocating particular ethical/political postures or paradigms. Rather, an object-oriented ontology is 'meta-political' and 'meta-ethical' in nature, in that it aims to outline the metaphysical framework within which matters of concern are formulated and disputed (ibid., 8), and where there is room for more-than-human perspectives. This is vital because, as the news story from LIGO blatantly recalls, 'a truly pro-object theory needs to be aware [also] of relations between objects that have no direct involvement with people' (Harman 2016, 6). If we forget this we are, paradoxically, claiming reality and the cosmos as a predominantly buman settlement, while simultaneously boasting about overcoming the subject-object divide (ibid.).

The need to rethink politics and ethics in a darker, more-than-human direction is evident. It is hinted at by black-hole mergers and gravitational waves, but maybe (for us) most clearly, and importantly, in the stirrings of current discourses around climate change, where the shortcomings of a normative, anthropocentric politics and ethics are becoming ever more clear. And similarly to what others have suggested, I believe that archaeology has something to offer in this endeavour (see e.g. Solli et al. 2011; Hudson et al. 2012; Edgeworth et al. 2014; Edgeworth et al. 2015; Harrison 2015; Lane 2015). For that to be realized, however, archaeology must also rethink some of its basic notions of what constitutes archaeological material, the conditions for how to approach or know this material, and the prospects for what should be the outcome of that effort. In other words, rather than limiting archaeology's significance to its culture-historical approaches, a wider understanding of the archaeological project is required.

To lay the ground for further discussion I will now turn to a case study focused on drift matter, or seaborne debris, in coastal regions of Iceland and northern Norway. Thinking beyond baselines and golden spikes, I want to use this material to consider questions concerning what comprises and confines (if anything) the matter of the Anthropocene, and in turn how the Anthropocene may alter notions of the archaeological record and challenge traditional 'archaeo-logics'.

\section{Matter in drift as matter of concern}

The very pulse of the sea, not only its perpetual motion, has us imagining that it is drawing breath. Inspirations and exhalations of a living, if unimaginably vast animal.

Zerzan $(2012,2)$.

The sea is often spoken of as the last great wilderness, a 'last remaining lair of unparalleled wildness' (Zerzan 2012, 1). The coastline, here, is a 


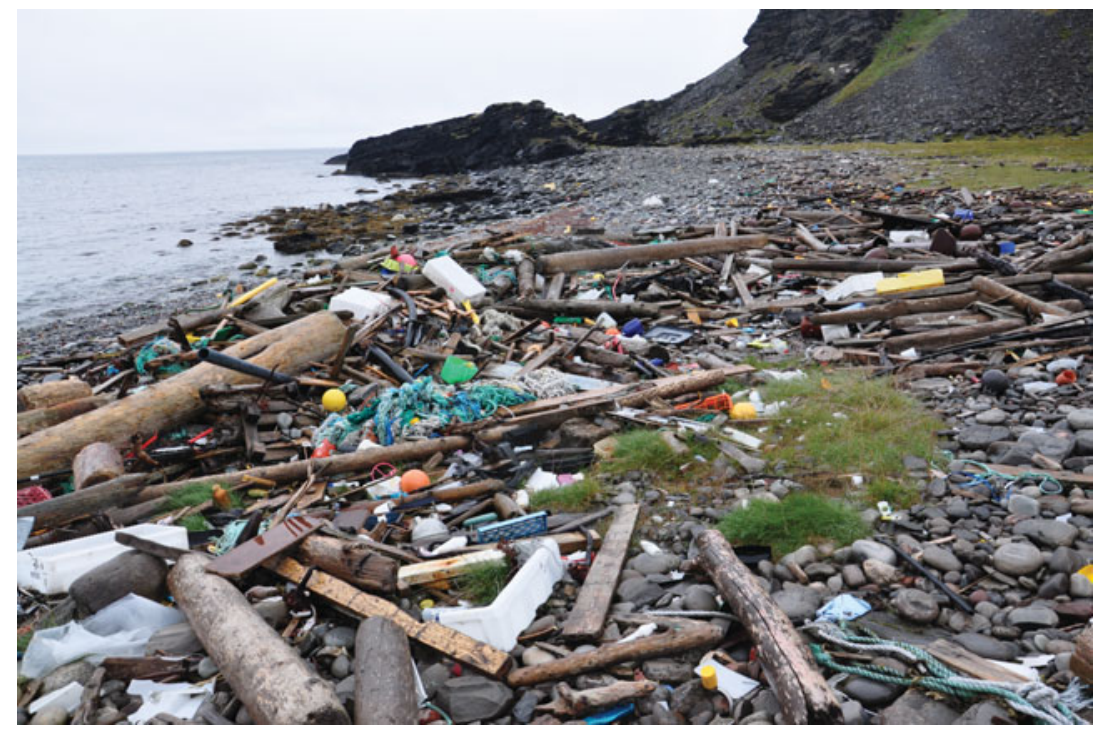

Figure 3 Entangled drift matter in the main wrack zone of Eidsbukta. Photo: Póra Pétursdóttir. (Colour online)

cultural frontier and meeting place; an edge where imaginations are born and explorations launched. It is almost too telling that along this imagined border, in the zone between the known and the unknown, culture and nature, we find things, accumulating in increasingly intimidating quantities - the unruly mongrel of material culture.

One example of such border assemblage is found in the cove of Eidsbukta (figures 3 and 4), located on the northern tip of Sværholt peninsula in Finnmark in northern Norway, at a latitude of just below $71^{\circ}$ north (Pétursdóttir forthcoming). Facing the open Barents Sea to the north-west, with the circulating surface waters of the north Atlantic current from the south and the Bear Island current from the north-west, the cove is ideally situated to capture enormous amounts of drift matter from incoming tide and storm. Its effectiveness is bluntly recalled in the name it was given by residents in the small, now abandoned, fishing hamlet on the east side of the barren peninsula: 'We always called it Driftwood Beach [Rekvedfjæra]', Gunnlaug Sagen states; 'that is where we went for wood' (Sagen, personal comment). This is something Eidsbukta shares with many other coves and inlets along the coast of Norway, Iceland and other north Atlantic shores, where names like Rekvika and Tømmervika (Norwegian); Rekavík, Keflavík, Stokkseyri, Bolungarvík, Borðeyri, Trjávík and Viðvík (Icelandic), recall the importance of driftwood along barren coastlands (Kristjánsson 1980, 199201). Here the drift beach was a natural resource on par with meadows, peat bogs, salmon rivers, lakes and bird colonies, ${ }^{4}$ and controlled even through formal resource management and legal regulation. ${ }^{5}$

For sure, and as clearly revealed in Eidsbukta, the current composition of beach assemblages in the north Atlantic is increasingly more complex than 


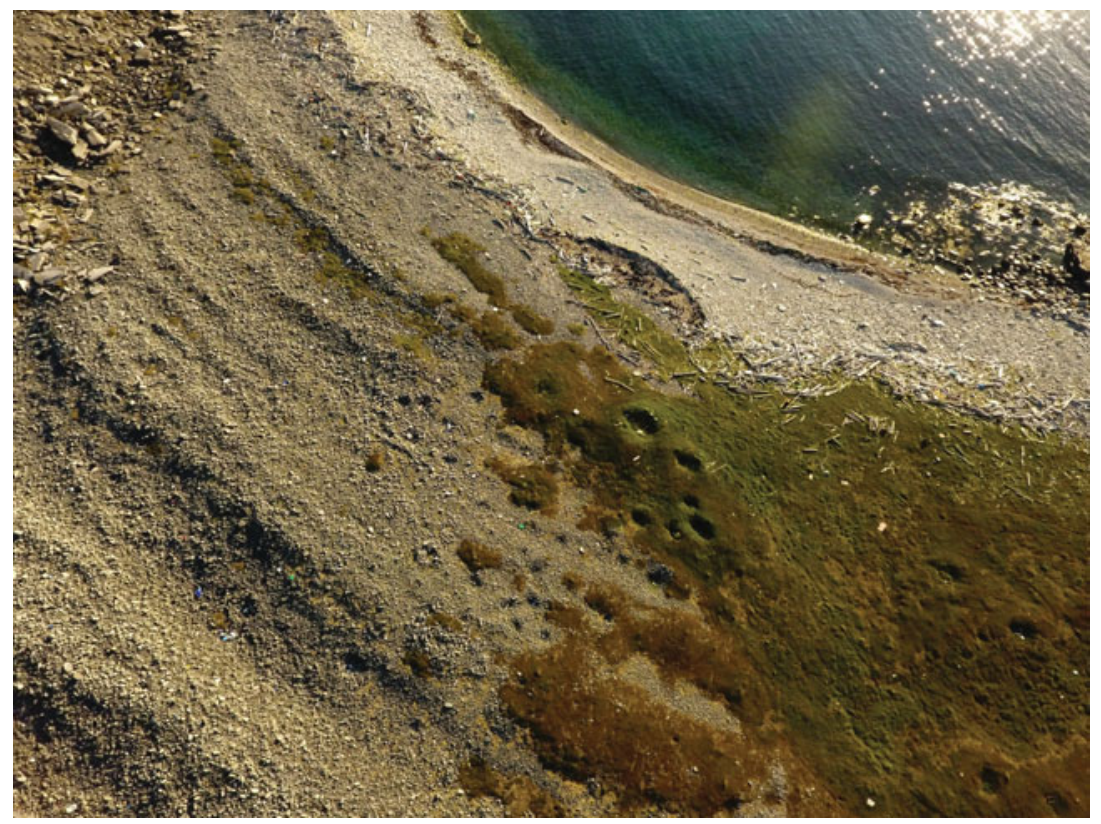

Figure 4 Drone photo of Eidsbukta with the fossil shorelines extending inland. Both wrack zone and transit zone are clearly visible. Photo: Ingar Figenschau. (Colour online)

pictured in these sources. 'Natural' driftwood can hardly be told from other wood, and is tightly entangled with other stuff: synthetic polymers of various sorts and shapes, containers, netting and fishing gear tumbled and entwined with kelp and seaweed, beach pebbles and sediments (figures 2, 5 and 6). This is not least tellingly reflected in the colours of these beaches, which today are densely decorated in hues starkly contrasting what is considered the native patina of these northern latitudes.

It is not surprising that notions of the drift beach have changed drastically through the last decades. Not only has drift matter become a mostly superfluous resource, it has also transformed from resource to pollution. While for a long time it was conceived of as matter in drift and thus part of an ecosystem, it is today seen as 'matter out of place' (Douglas 1966), a modern intrusion in 'natural' environs. And not without reason. Marine debris is one of the most alarming global problems we face at present, and among the most conspicuous manifestations of the Anthropocene.

Marine debris Marine litter or debris has been defined as 'any persistent, manufactured or processed solid material discarded, disposed of or abandoned in the marine and coastal environment' (UNEP 2009; see also Coe and Rogers 1997, xxxi). It is a phenomenon found along shorelines and waterways all over the world, and has, since its first mention in science literature in the 1960s, been a growing concern of environmental research. Not least after the discovery of several mid-ocean garbage patches and the identification of microplastics $(<5 \mathrm{~mm}$ ) in ocean bodies in the early 2000s (Ryan 2015). 


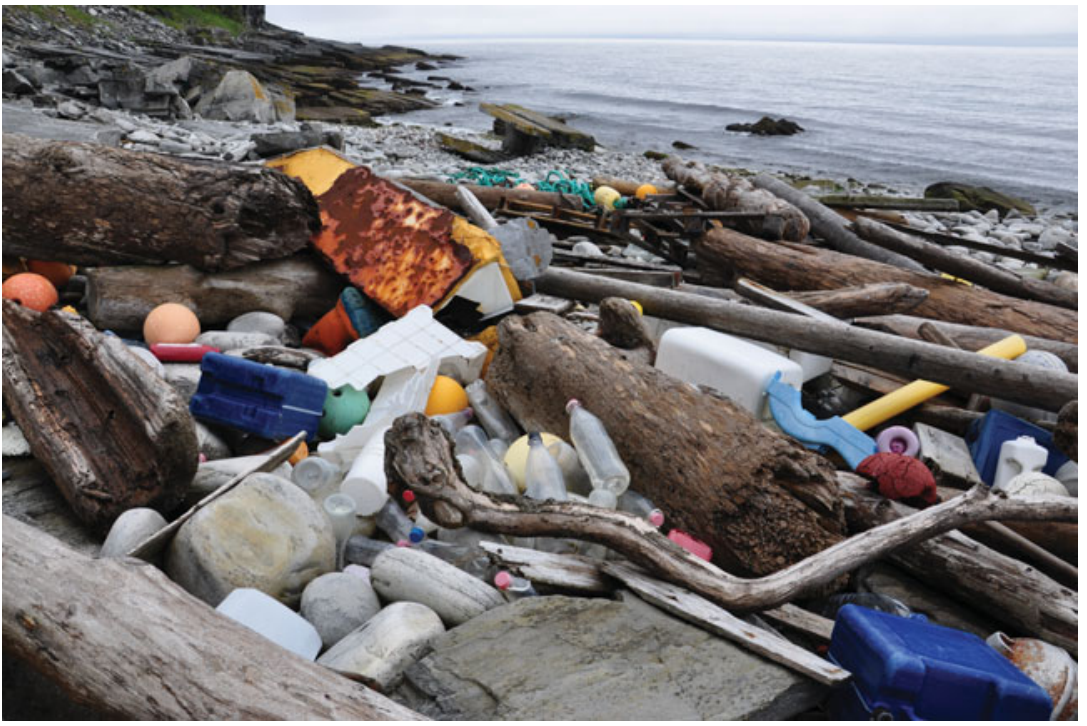

Figure 5 Drift matter in Eidsbukta: driftwood, worked wood, pallets, plastic bottles and containers, fishing gear, seaweed, childrens' toys, steel, rope, boots, rocks and pebbles. Photo: Póra Pétursdóttir. (Colour online)

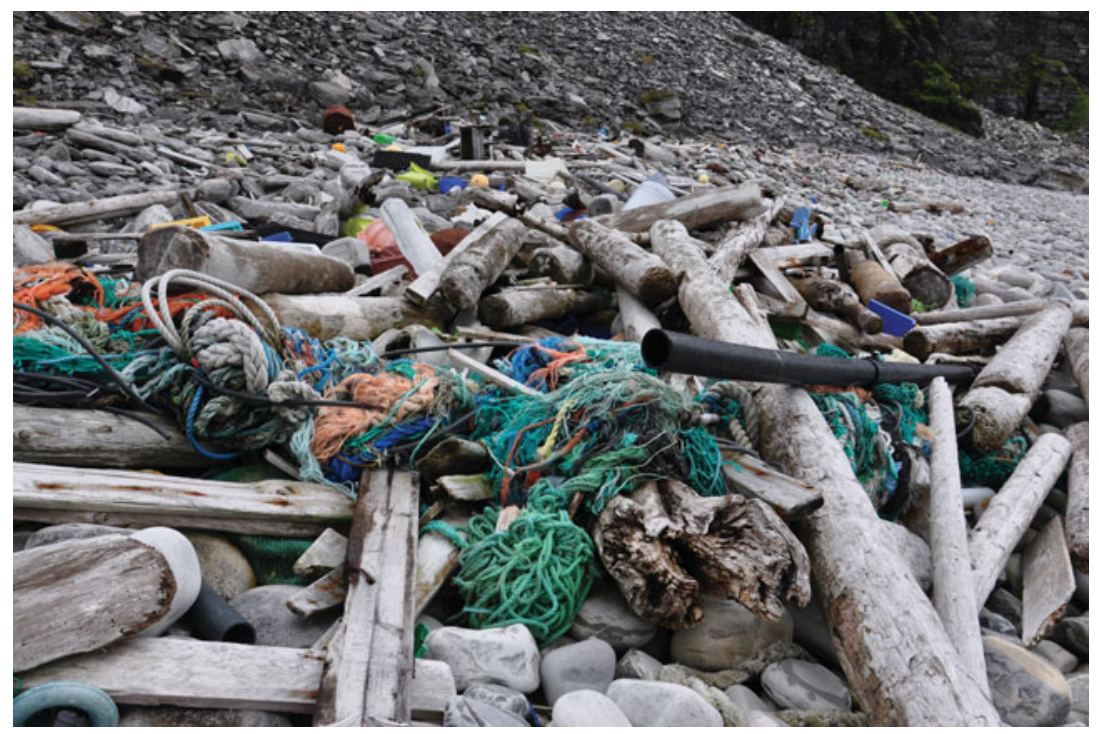

Figure 6 Tumbled and entangled beach compound, Eidsbukta. Photo: Póra Pétursdóttir. (Colour online)

Because this is drifting matter it is difficult to establish enduring statistics regarding the abundance, distribution and composition of marine debris. Local variations are considerable and may also change as the effect of singular events. It can be stated, however, that marine debris is found in all realms of marine environments, adrift in coastal and open waters, in lower levels of 
the pelagic zone and on the ocean floor, as well as stranded on beaches (from where debris may travel further inland or out to sea). Depending on local conditions the debris is of both land- and sea-based origin and things may, moreover, travel long distances from source to stranding (Galgani, Hanke and Maes 2015; Thompson 2015). Following this, global surveys have shown that anthropogenic litter has colonized the remotest of islands and regions (Barnes 2005; Barnes, Walters and Gonçalves 2010; Bergmann and Klages 2012; Bergmann et al. 2016), including the deep sea floor (Ramirez-Llodra et al. 2011; Pham et al. 2014; Woodall et al. 2014).

The sources of marine debris are various, and may range from general public and recreational littering to sewage and landfill overflows, industry, fishing vessels, offshore platforms and commercial shipping, but also extreme singular events like tsunamis (Coe and Rogers 1997; Galgani, Hanke and Maes 2015). Debris composition also varies, although it is indisputable that plastics make up a considerable part of the debris currently afloat or stranded in marine environments - even accounting for up to 95 per cent of locally documented debris (Galgani, Hanke and Maes 2015, 30), whereof up to 92 per cent is constituted by micro-scalar particles (Eriksen et al. 2014). It has further been assessed that 10 per cent of all plastic waste debris produced eventually ends up in ocean bodies (Thompson 2006), where it may remain and slowly break down to micro- and nano-particles for futures to come. This being said, statistics are more abundant and reliable for beaches, surface waters and the upper pelagic zones, and the composition of debris in lower levels or on the ocean floor may differ from these (Ramirez-Llodra et al.2011).

These alarming numbers refer to what is defined as anthropogenic litter. However, as most beach assemblages reveal, this material is extremely mixed, and rather obscures distinctions between nature and culture, ecofact and artefact. This is manifested also in the calamitous fact that micro-particles have already entered the food chains of several species, including our own (Galloway 2015; Lusher 2015); further, with the identification of so-called plastiglomerate, a petrified hybrid of plastic, rock and beach sediment, a physical marker for the Anthropocene in the geological strata has recently been suggested (Corcoran, Moore and Jazvac 2014; Zalasiewicz et al. 2016).

Drift matter in Eidsbukta Most of us are familiar with these coastal 'wrack zones' - the shelves just above the part of the shore that slopes down toward the water, where high tide and winter storms relentlessly deposit layer upon layer of kelp, driftwood, things and debris. Childhood memories from days on the beach may recall wondrous archaeological explorations in such exotic zones, digging through slimy or shrivelled piles to encounter strange things washed ashore from far-away places. Nostalgia aside, or rationalized, however, it is as likely that most will think in terms of pollution and ecological threat when recalling or encountering these exotic zones, as it is unlikely that anyone will think of cultural heritage in this relation. This is reflected also in the interesting fact that these extremely rich 'cultural deposits' have mostly escaped archaeological interest (see, however, Arnshav 2014).

That said, grasping drift matter with traditional archaeo-logics is not simple. Surely, archaeology is deeply concerned with waste, which most 


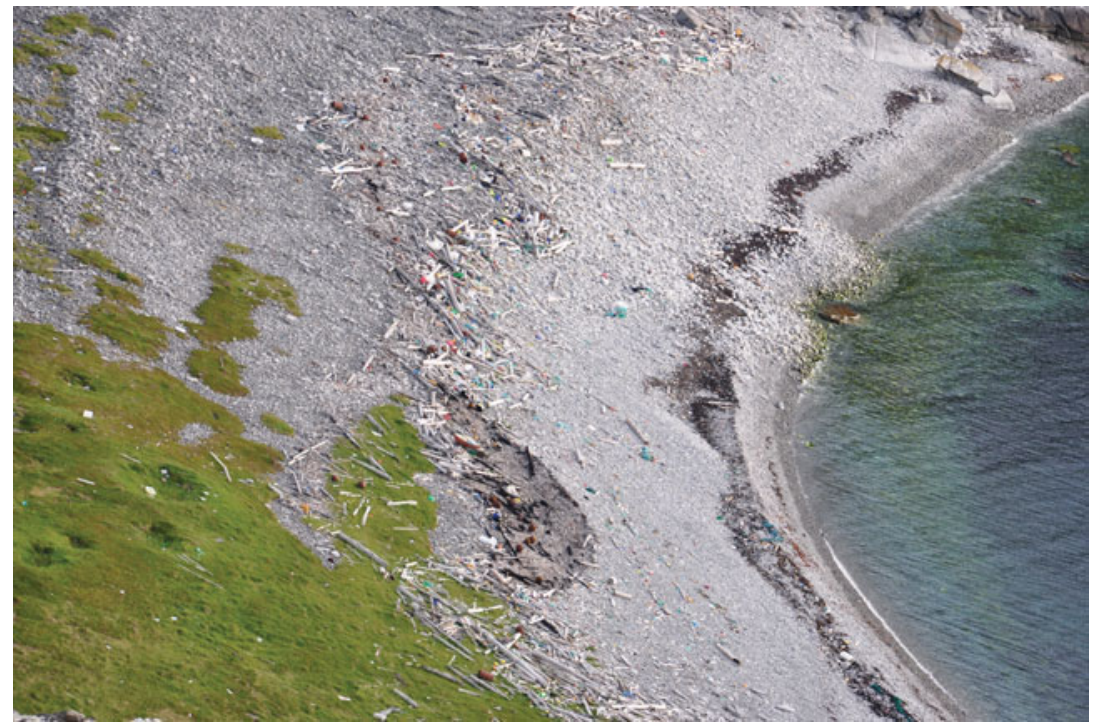

Figure 7 Belts and ripples of drift matter, Eidsbukta. Photo: Póra Pétursdóttir. (Colour online)

would associate this material with. Archaeological waste, however, mainly belongs to a culturally specific and already meaningful context. Much like gravitational waves washing past Earth, the tidal deposits on beaches like Eidsbukta wash in from a spatio-temporal distance. Hence, rather than 'waste', which is already a sociopolitically charged designation, these tumbled vagabonds are, above all, drifting - literally and conceptually.

Images of surface assemblages in Eidsbukta (figures 1, 2, 3, 5), and of the compound's interred strata (figure 1), reveal this to some degree. A closer look, and a lengthy engagement with the beach, will make this even more conspicuous, exposing how matter referred to as 'stranded' is in fact matter in motion; rather than marooned it is caught in the process of drift. This is visible both in a horizontal plane and in the beach's vertical strata (figure 1). On the surface, Eidsbukta is laid with the contours of fossil shorelines (figure 4); formed through the post-glacial land uplift they extend inland, repeating the cove's outline like ripples in water. Along the lowest of these ridges is the main wrack zone; a thick and coarse belt of debris stretching from one end of the cove to the other, topographically reflecting the discrepancy and continuity between Holocene and Anthropocene (figures 4 and 7). But also above and below this zone are ripples of matter in motion. In what may be called the 'transit zone', between the main wrack zone and the shoreline, are finer, more fragmented belts of material slowly travelling or tumbling inward (or outward) with the tide (figures 7 and 8). With time, these strings of wood, plastic, kelp and debris may eventually join and add to the main ridge. Meanwhile, they are gently, and sometimes forcefully, driven about as if inhaled and exhaled by the tide.

Further up, extending inland from the main ridge, is a zone of windblown material - mostly plastic - travelling further inland and becoming 


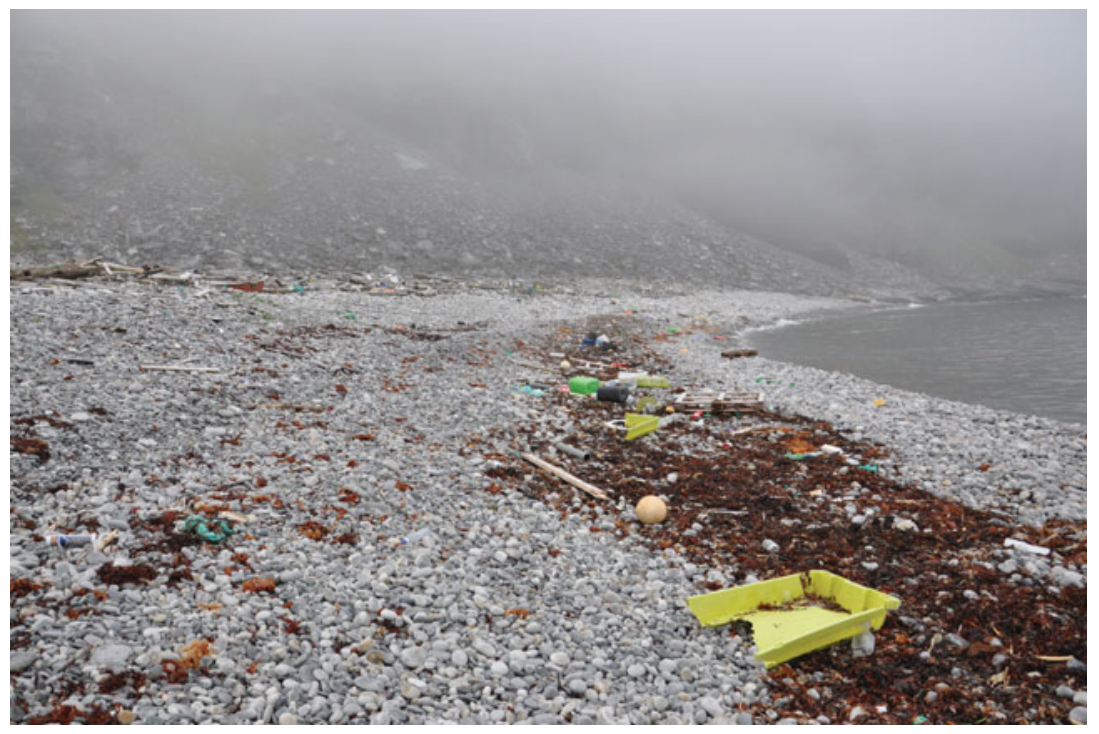

Figure 8 The transit zone: plastic, wood, kelp and more. The main wrack zone is visible on the ridge to the left. Photo: Póra Pétursdóttir. (Colour online)

increasingly dispersed and scattered along the way (figure 4). Most of these things are light and easily blown, while others bear witness to the incredible forces escorting them inland. Here, material also gathers along topographic features, finding harbour and sympathy in pits and recessions, which often represent archaeological structures. Like prehistoric hunting pits they capture their prey from the slowly bypassing herd, hold on to it like precious booty, to create strange, accidental assemblages of interred articles.

In addition to drift registered on the surface, there is also an ongoing dynamic extending below the top cover, as registered through the excavation and section clearing reported at the beginning of this paper. Though it may appear as a vertical motion or build-up, this force more resembles a circular, tumbling current, emulating in a slow and weighty manner the breaking of waves on the shore. Like an unseen, roaring undercurrent, it tumbles the material of the beach, mixing it together, burying and tangling it in the depths so that it may never again be undone. Through this ruthless drive the material also becomes ground and crushed between beach pebbles into ever smaller pieces, to lastly endure as brightly coloured freckles - 'confetti' - flickering in the beach sand.

Eidsbukta is surely a very rich beach. Nevertheless, similar assemblages can be found in coves and inlets all across the north Atlantic, and elsewhere. Considering the prospects of an archaeology in/of the Anthropocene, the ruthless amassing of this material seems hard to ignore. While we may argue that the dawn of the Anthropocene should be traced back to the heyday of agriculture or to the harnessing of fire, we must agree that assemblages like these, together with, for example, nuclear waste, GMOs, polluted soils and space debris in orbit, are of parallel importance when considering the 
current climate situation. How to approach them as matters of archaeological concern is, therefore, an imperative question for an archaeology in/of the Anthropocene. That said, this material has for long escaped archaeological interest, and incorporating it as part of the archaeological record may also instigate some serious jolting of the archaeological imagination, which I will now turn to.

\section{Obstacles to an archaeology in/of the Anthropocene}

Following a discussion of drift matter as matter of concern in the Anthropocene, an obvious, though possibly banal, question is, why has this material hitherto not been considered of archaeological interest? Archaeology is 'the discipline of things'. What about these things? What are they possibly lacking, or what is required of them to become archaeological? Attempting to answer these questions, I will now present some thoughts on the prospects and challenges of an archaeology in/of the Anthropocene. Conversing with what I have above identified as some of the key tropes of current archaeological responses to matters of the Anthropocene, I will suggest some alternative perspectives. These are summarized through six proposed obstacles, unavoidably overlapping, and a discussion on how these may hint at needed radicalizations of the archaeological project.

Culture bistory A first obstacle of an archaeology in/of the Anthropocene regards culture history and archaeology's hesitation with really considering non-human contexts and non-human agency (see, however, Olsen 2010; 2013; Olsen et al. 2012; Nativ 2014). As I have argued, common notions of archaeology's responsibility and ability to contribute when it comes to matters of the Anthropocene relate to the depth of archaeological culture history. This is important both in terms of providing knowledge from the past to prepare for a better future, and for a more nuanced understanding of the new era, its nature and chronology. While this represents a significant and truly archaeological insight, some less anthropocentric perspectives would also be of value.

While the non-buman and things' agency have for long been part of archaeological research focus, the actual ability of things to exceed human relations may, on closer look, still be rather limited. Things mostly appear as active, or as actors, when in collaboration with $u s$ or when acting directly upon us. This also holds for the biographical approaches often employed to underscore the agency of things (e.g. Kopytoff 1986; Hoskins 1998; Gosden and Marshall 1999; Holtorf 2002). These biographies are mostly confined to the phases in things' lives they share with us, either in the past, in the service and company of past human actors, or after their retrieval when forming new meaningful relations with archaeologists, curators, museum visitors, and so on. It is almost as if things themselves, and their past time drift, between these phases of human interaction, barely existed at all. Yet, as put by Max Liboiron $(2016,103)$, 'In the Anthropocene, the "afterlives" of industrially produced objects are the longest part of their lives'. And as archaeologists, we can state that this very often holds for humanly produced objects regardless of chronological context. 
The main reason why the wrack zone assemblages of Eidsbukta and other beaches evade archaeological attention is probably found here, in the unintentional character and the ex-human drift and accumulation of the material. Though sources of origin and past functions may be reconstructed for much of this material, it is perhaps most informative of things' 'postbuman' lives. More than throwing light on the faults of waste management, it reveals a domain that goes beyond human domination and control. Rather than 'matter out of place' it resembles what is called material out of context - 'stray finds' - which renders them alien to the preferably buman or culturehistorical past that archaeology seeks to reconstruct.

Therefore, in order for archaeology to grasp material of this kind (which partly constitutes the empirical ground of the Anthropocene), it is crucial also to consider such less anthropocentric contexts. While recognizing things' agency, we cannot reduce them to useful means and supportive collaborators. An archaeology in/of the Anthropocene must think of things 'as sleeping giants', as Harman (2016) puts it, which hold in reserve arrays of unforeseen capacities and unexpected alliances that far exceed any current relations and functions - and which may or may not involve direct human associations.

The archaeological record Following this, a second obstacle concerns the archaeological record. We tend to think of the archaeological record as a residue of something gone, and thus a medium through which to reach that human past. Our engagement with it is a form of translation, where fragmentary and unruly things are, ideally, interpreted into an orderly and coherent chronological/historical sequence. In other words, the archaeological record is generally approached as proxy data, whether or not we choose to refer to it as such. What is at risk of becoming lost in the process of translation is the character of the record itself, how it strikes upon encounter and how it possibly (dis)obeys notions of coherency, and breaches parameters of interpretation. In fact, it is the urge to establish order and cultural meaning that grounds the enduring understanding of the archaeological record as incomplete - the mere remainder of a total record (Lucas 2012, $18 \mathrm{ff}$.) - and thus something in need of adjustment in order to be resettled as history (Olsen 2012). This deficiency is not inherent in the material itself, but a construct of archaeological expectations.

To underline this, scarcity is most likely not what comes to mind when reaching shore in Eidsbukta, scavenging a landfill or traversing the Pacific gyre. It is only if the aim is to force the material through a traditional culture-historical cleansing and translation that its 'deficiency' and lack of collaboration become evident. Therefore, I argue, what an archaeology in/of the Anthropocene must do in order to take assemblages like these seriously is to establish more trust in things/materials themselves, and in the archaeological record as a more-than-human (more-than-cultural) record. Not in the sense of identifying disturbing 'post-human' influences on the material remains, but in the sense of recognizing that the record is alwaysalready truly mixed, and that this, moreover, is what forms the existential condition for any being (including human beings), also in the past. 
In a text on scientific method, Carlo Ginzburg $(1980,27)$ noted, 'Reality is opaque; but there are certain points - clues, signs - which allow us to decipher it'. While this holds a truth, important clues may also lie in opacity itself (cf. Sørensen 2016), and some matters of concern, not least regarding notions of the Anthropocene, may evade the semiotics of deciphering. Viewed in this way, the unruliness of an assemblage like the wrack zone in Eidsbukta, and the fragmentation of its compositional entities, may be transformed from being anomalies in need of translation, to instead manifest a different, dark side of things, revealing how they endure and outlive us, and how they interact outside our control and domain.

Deep time, distant pasts The third obstacle I propose concerns the focus on deep, stratified time and distant pasts, which traditionally are claimed to be crucial to the archaeological project. These fundamental tropes are often revived when arguing for the importance of archaeology and archaeological knowledge in the face of the Anthropocene. Archaeology's deep prehistorical perspective and familiarity with the 'artificial ground' or 'archaeosphere' (Edgeworth 2013; Edgeworth et al. 2015) that constitutes the geology of the Anthropocene enables it to contribute with knowledge, nuance and critique in debates around human ecodynamics, chronology and stratigraphic baselines.

Notwithstanding the significance of the longue durée of retrospection, however, the irony of the Anthropocene is that it is born out of a condition where the past is not distant but haunting. A condition where it is becoming ever more clear that the past does not have to be retrieved or rescued, but is overwhelmingly present and threatening. Hence a paradox of this 'Age of Man', as argued by Liboiron $(2016,103)$, is that it 'both centralizes and decentralizes humans' and their 'role in the longue durée of planetary systems' (ibid., 104). Not in the sense of questioning the gravity of the situation, or humans as actors (and partly responsible), but by foregrounding how, in a world that is temporally mixed and polluted, tropes of anthropocentric measures, human time and human pasts are unable to fully articulate the intricacy of socio-material relations.

Rather than relying solely on traditional notions of deep, linear time and distant pasts, what an archaeology in/of the Anthropocene must cope with is a notion of contemporaneity and coincidence, a temporality, as the one so conspicuously reflected in marine debris and beach assemblages, where past and present coexist, drift and merge. The matter of contemporaneity is eloquently debated in a recent article (Lucas et al. 2015), where Gavin Lucas argues for a notion of contemporaneity as 'consociation'. The 'contemporaneity of the archaeological record', he states, 'is not about its existence in our present, but rather about its particular mode of persistence that interconnects past, present and future' (Lucas 2015, 11, emphasis added). In other words, rather than pertaining to a notion of an abstract, sequential time, archaeology's temporality is grounded in relations between things, and the archaeologist's task is to 'trace gradients of consociality' or 'gradients of reciprocity' (ibid. 12, 14, original emphasis) to identify relations of significance. This is vital for an archaeology in/of the current climate. 
Equally important, I argue, is to ensure that gradients of significance are not confined to specific shades of being, acting and meaning. In other words, tracing meaningful affairs in the Anthropocene cannot be kept to an identification of social relations in a traditional sense. Indeed, what is recognized as Anthropocene is possibly better captured with reference to conglomeration rather than consociation; ${ }^{6}$ relations where things erupt out of humanly defined functions, categories, coordination and meanings become blasted out of history (cf. Benjamin 2003), to drift and wash ashore into other, less familiar, but at present no less significant, associations. As argued by Harman (2016), a sincerely pro-object theory is also attentive to those relations between things that exceed direct human involvement. This is not to argue that things have intentions or agendas, but simply that their capacities of becoming (matters of concern) surpass our agendas. And a challenge of an archaeology in/of the Anthropocene is to acknowledge this dark side of things, and find ways to render seemingly futile processes of 'asocial' drift, accidental affairs, quirks and post-human relations meaningful without explaining them away through social and cultural semiotics.

Stratigraphy, hierarchical relations and drift This brings me to a fourth, kindred obstacle, which relates to stratified time, hierarchical relations and drift. Archaeology has traditionally not only adhered to the modern understanding of time as linear and sequential, but has importantly also contributed to the manifestation of this understanding. Periodization and typological series, for example, may reinforce this by depicting cultural change as substitution.

Another paradox of the Anthropocene and climate change is that in essence it has as much to do with the persistence of objects and object relations as with change. As Harman (2016) has reminded us, things act because they exist and not the other way around. And it is because they endure and continue to relate to other human/non-human objects in the environment (and thus affect our being) that the Anthropocene scenario has unfolded. It is not a matter of change through substitution, but of change through persistence, drift and accumulation. Another challenge for an archaeology in/of the Anthropocene is to think beyond clear-cut stratified, hierarchical relations, and beyond a binary pairing of stability and movement, to emphasize matters of duration, palimpsests, entanglements and quantum leaps.

If we look at development in archaeology and archaeological theory over the last two decades, mobility and movement have in many ways been central. One could claim that with the breakthrough of a notion of agency, and more importantly of things' agency (especially through ANT and biographical approaches), everything became a matter of movement and flux: things are actively involved in social relations; they are fluid, and their meaning and identity are in a constant process of becoming. As a consequence, references to stasis and stability appear oddly conservative, backward and outmoded (cf. Ingold 2007; Olsen 2010; Pétursdóttir 2012). This also relates back to a point made earlier regarding a reluctance to consider things' life beyond humanly defined and coordinated relations, and their significance as something unconfined to meanings afforded through such occasional human affairs. 
The notion of Anthropocene, one may argue, has also manifested a notion of thing agency, and hence rendered imperative the question of how to attend to this agency. However, whereas the delineation of things' biography proved extremely fruitful in articulating their social significance, matters of concern in the Anthropocene may suggest that general analogies to 'life' and other anthropomorphic measures distort rather than help such attentiveness (cf. Braun and Whatmore 2010; Liboiron 2016). In other words, 'material specificity matters for action' (Liboiron 2016, 91) and non-human agency neither equates to nor necessarily respects human agency. Archaeology in/of the Anthropocene must, I argue, refrain from opposing stagnation and movement, persistence and change in order to be open for other routes of meaningful becoming.

While the archaeological record may provide valuable information for a potential chronological definition of the Anthropocene, it may also, and importantly, provide insight into how the 'relative immortality' of things dissents such clarity. Recalling again that 'reality is opaque', a confident engagement with the unruly sedimentation of things as a meaningful existential condition in itself should therefore be of concern for an archaeology in/of the Anthropocene.

Locality and the archaeological assemblage A fifth obstacle has to do with notions of locality and the archaeological assemblage. Traditionally, meaning in archaeology is constructed through the inherent, hierarchical ordering of archaeological assemblages confined to certain localities, and relations between these. What is characteristic of much of what we can call 'objects of the Anthropocene', however, is that they do not abide by such confining measures. They are, as argued above, out of hand (Pétursdóttir 2014) or blasted 'out of context'. Recalling the wrack zone in Eidsbukta, this is not really telling of past sociopolitical or culture-historical relations at the site. Drifting in from afar, transforming and engaging along the way, things' channels may or may not be traced but will in any case not fully explain or grasp their presence and relations on the beach. One challenge of an archaeology in/of the Anthropocene is to develop means and measures to meaningfully engage with, and articulate, this kind of presence and persistence.

In his critical and dark ecology, Timothy Morton has coined the term 'hyperobjects' to grasp some of these elusive phenomena, like radioactive waste or $\mathrm{CO}_{2}$ emissions - or marine debris. According to Morton's (2013, 1) definition, hyperobjects are 'things that are massively distributed in time and space relative to humans'. They are entangled and stretched in a way that makes it meaningless or impossible to think in terms of single objects and isolated locations. They are in essence non-local - spread all over - like ripples in space-time, and involve temporalities that are vast compared to a human-scale temporality. And finally, they act interobjectively; they become afforded in the spaces where different objects and properties interact (ibid.).

Without ignoring human agency and responsibility, archaeological assemblages like wrack zones and marine debris require that we acknowledge hybrid, non-local and beyond-human conduits of this kind. These assemblages 
may or may not involve human agency, but cannot be tackled without considering things' own endurance, their dark sides, and the consequential interactions between non-human entities, between plastic bags, sewage, fishing nets, currents, driftwood and drift ice, seagulls, temperatures, UV rays, winter storms, prehistoric marine terraces and the Moon's gravity. It is acknowledging this conglomeration and our often insignificant place within it that must inform an archaeology in/of the Anthropocene.

Nature cultures and environment This brings me to a final obstacle, namely the nature-culture divide and other understandings of 'environment'. Preaching about the need to deconstruct the nature-culture dichotomy may appear rather dated, or even out of synch, as we have long since moved beyond this in archaeology. Nevertheless, and as I have mentioned, there are certain indications that much of the Anthropocene discourse, outside and within archaeology, reintroduces and reinforces an understanding of man as somehow apart from nature. On the one hand, his doings are polluting an outside environment, and on the other, his superior intellect and creativity are to fix the problem. As Ian Hodder states in his reflections on human-thing entanglements,

Over the course of human evolution, the expansion of entanglements has meant that all aspects of the environment have become human artifacts. There is less and less outside the human that can 'take care of itself.' The whole environment (in the Anthropocene) is itself an artifact needing care, fixing, and manipulation (Hodder 2014, 32-33).

Recalling one of the three key elements of an object-oriented realism discussed above, and as palpably recalled also on the shores and in the sediments of Eidsbukta, things are more than what they are doing right now; they have a 'dark side' that exceeds our knowledge of them, and which is far from exhausted by any momentary entanglements they may have with us. This is the constitution of the Anthropocene scenario. While there is little sense in refuting that we have made a mess in our planetary home, what makes the Anthropocene distinctive does not have to do with us alone, but involves other species, materials, stuff, machines and the complex relations between these different entities (Lucas 2011, 67-68; LeCain 2015). And far from underestimating our part in the mess, or 'mesh', Nature, and the idea of Nature, are importantly part of the problem (Morton 2007).

However, replacing a nature-culture dichotomy with a notion of 'ecological interdependence' - an eco-network composed of reciprocal relations between equally dependant beings - which is often hinted at, may not do the trick either. To recall Ian Bogost's $(2012,11)$ brilliant framing, 'all things equally exist, yet they do not exist equally', and as argued by Nigel Clark and Mira J. Hird (2014, 51, original emphasis), the fact is that 'we are, above all, dependent'. For example, our very existence is enabled and conditioned by bacterial life in ways that vastly outweigh these same bacteria's dependence on us or our offerings. The bigger picture may even reveal that 'we are the fallout of the dynamics of bacterial becomings' (ibid., 50, original emphasis). As a result, calling ourselves the stewards of heritage, of the environment, of the 
planet, and of a potentially good Anthropocene (not to mention the naming of this new era) arrogantly misrepresents our place in this environment and our very dependent being. Therefore, and importantly, what an archaeology in/of the Anthropocene calls the 'environment' or the 'cosmos' must not be a web of balanced and harmonious relations, but rather full of asymmetry, full of darkness, and full of regions devoid of human presence and unmoved by both our concern and our ignorance.

\section{To conclude: beyond proxy and culture history}

Icelanders have a common saying, að ganga á reka, which literally means 'to walk the drift'. The direct analogy is the drift beach resource and the collection of wood, while the derived meaning is to walk in search of something, or rather to walk and see what may drift toward you. This saying guided my research in Eidsbukta and on other drift beaches in northern Norway and Iceland. I did not know how to approach this material. I had no means to do so. Hence what became imperative to my work was to walk the drift, to trust the material itself, and learn the challenges, the means, the notions, the principles these things seemed to afford.

As reflected in its etymology, archaeology is mostly understood as the study of the past and archaic, the primeval. As a modern scientific discipline it is, moreover, considered to concern a reconstruction of that past by systematically making sense of the fragmented data it left behind. These central archaeological skills, of stratigraphic readings of sequential time, knowledge of a deep culture history and means to revive distant pasts, are among the important affordances often stressed in relation to an archaeology in/of the Anthropocene. However, archaeology is also, simply, the discipline of things. And its arkhe, or beginning, irrespective of chronological focus, is with things here and now - in moments of encounter that precede explanation. In other words, archaeology begins with fragments and with conglomeration, which is what constitutes its drive but also, and importantly, its existential condition. It is this beginning, I argue, that is archaeology's most important asset in the turmoil of the current climate.

Though seemingly a rather banal argument, stressing this initial condition of our craft does require a certain rethinking of the archaeological project and reaffirmation of the archaeological imagination. That is, we might allege for much of contemporary archaeology what Jeff Malpas $(2012,265)$ has claimed for contemporary philosophy, that it may

begin in wonder, but inasmuch as the demand for explanation constitutes a demand for illumination and transparency, so it can also come to constitute a blindness to ... the prior belonging to the world that first drives the demand for explanation as such. Philosophy begins in wonder, but it often ends in alienation ...

I do not contend that making sense of things by reconstructing past relations and narrating culture histories is a practice of alienation. However, when it comes to matters of the Anthropocene, it is no less important not to overlook the 'prior belonging to the world that first drives the demand for explanation as such' (ibid.), and the often genuinely anarchic, unruly conglomerations 
constituting that world. This mixed existential condition is the prime matter of concern in the Anthropocene, not as a problem to be solved or as a proxy for something else, but as the initiation of our being, thinking and action.

Returning to Eidsbukta: if we take seriously the agency of this material - how things are drifting and gathering on the verge of the 'human realm'

- it brings into question some central notions of the Anthropocene and of archaeology, while also holding some clues as to how we may proceed. Having escaped human relations, to become 'out of hand' (Pétursdóttir 2014), these things contest our traditional culture-historical approaches. For one thing, the pasts they have witnessed are too radically different from the humancentred history we mostly wish to recover. And just as they fail as historical witnesses, their immediate, pestering presence and continuous accumulation also render them too unruly, too aggressive to be settled as proxy data. And this is what simultaneously makes them terrifying and renders them matters of vital concern: that they do not represent anything coherent or expectedly humanly rewarding (past, society, culture, and so on) - but are above all presence.

This jolt of the imagination is what must guide the dark ethics and politics of an Anthropocene archaeology. It is the persistency of such hyperobjects as seaborne debris - things that spill over, drift and endure - that has underpinned the emergence of this new era. And it is through placing our trust in these very objects and the opacity of their existence that a radicalization of archaeology, of archaeological politics and ethics, must happen. Not by domesticating them through historical tropes, or expecting them to comply with the civil morals infusing our politics, or the buman rights grounding our ethics, but by taking them seriously as they appear, drift and withdraw.

Moreover, the challenges that these hyperobjects of the Anthropocene manifest so clearly may on closer look have much in common with the obstacles we face in our dealings with more traditional but no less unruly archaeological objects. Hence the 'ontological turn' and ideological 'climate change' we have to tackle is maybe less about rethinking and more about realizing the radical potential that the archaeological project already holds in reserve.

\section{Acknowledgements}

I am deeply thankful to Bjørnar Olsen and Chris Witmore, with whom I have traversed the beach assemblages of Eidsbukta several times, and who have thoughtfully discussed and commented on my arguments in this paper. These arguments were first presented at the RATS symposium, Binghamton University, in March 2016, and my thanks also go to the hosts and participants of this event, especially to Rui Gomes Coelho and Maura Bainbridge. In finalizing the article I have benefited from thoughtful discussions with several people, especially my colleagues in the two research groups Object Matters and After Discourse, and from the careful readings of Tim Flohr Sørensen, who commented on its final draft. Finally, I thank CAS, the Centre for Advanced Study in Oslo, where this paper took its final form. 


\section{Notes}

1 This paper was originally prepared as a keynote for RATS - Radical Archaeology Theory Symposium - in Binghamton, March 2016.

2 See www.sciencemag.org/news/2016/02/gravitational-waves-einstein-s-ripples-spacetimespotted-first-time.

3 See www.seeker.com/hawking-gravitational-waves-could-revolutionize-astronomy1770882019.html.

4 This is the case, e.g., in the early 18th-century Icelandic land registry Jarðabók Árna Magnússonar og Páls Vídalín (1702-14) (Copenhagen and Reykjavík, 1913-43).

5 The earliest Icelandic law code, Jónsbók (1281), includes extensive chapters on drift material, which are in fact still effective (last updated in 1999). These regulations are mostly concerned with driftwood, but also consider other forms of drift material (see Kristjánsson 1980)

${ }^{6}$ It should be stated that Gavin Lucas's notion of consociality and his discussion of the concept are not related to the Anthropocene. Rather than as critique, this should therefore be read as an attempt to extend his valuable considerations of contemporaneity to matters of the Anthropocene.

\section{References}

Ackerman, D., 2014: The human age. The world shaped by us, London.

Arnshav, M., 2014: The freedom of the seas. Untapping the archaeological potential of marine debris, Journal of marine archaeology 9, 1-25.

Barad, K., 2007: Meeting the universe halfway. Quantum physics and the entanglement of matter and meaning, Durham, NC.

Barnes, D.K.A., 2005: Remote islands reveal rapid rise of southern hemisphere sea debris, Scientific world journal 5, 915-21.

Barnes, D.K.A., A. Walters and L. Gonçalves, 2010: Macroplastics at sea around Antarctica, Marine environmental research 70, 250-52.

Benjamin, W., 2003: On the concept of history, in Benjamin, Selected Writings 4, 1938-1940, Cambridge, MA, 398-400.

Bergmann, M., and M. Klages, 2012: Increase of litter at the Arctic deep-sea observatory Haugsgarten, Marine pollution bulletin 64, 2734-41.

Bergmann, M., N. Sandhop, I. Schewe and D. D’Hert, 2016: Observations of floating anthropogenic litter in the Barents Sea and Fram Strait, Arctic, Polar biology 39(3), 553-60.

Bogost, I., 2012: Alien phenomenology. Or what it's like to be a thing, Minneapolis.

Braje, T.J., 2016: Evaluating the Anthropocene. Is there something useful about a geological epoch of humans?, Antiquity 90, 504-12.

Braje, T.J., and J.M. Erlandson, 2013: Looking forward, looking back. Humans, anthropogenic change, and the Anthropocene, Anthropocene 4, 116-21.

Braje, T.J., J. Zalasiewicz, C.N. Waters, S. Dalby, and A. Randall, 2016: Forum. Debating the Anthropocene, Antiquity 90, 504-18.

Braun, B., and S. Whatmore (eds), 2010: Political matter. Technoscience, democracy, and public life, Minneapolis.

Brewington, S., M. Hicks, Á. Edwald, Á. Einarsson et al., 2015: Islands of change vs. islands of disaster. Managing pigs and birds in the Anthropocene of the north Atlantic, The Holocene 25(10), 1676-84. 
Bryant, L., 2011: The democracy of objects, Ann Arbor, MI.

Bryant, L., 2014: Onto-cartography. An ontology of machines and media, Edinburgh.

Bryant, L., and E.A. Joy, 2014: Preface. Object/ecology, O-zone. A journal of object-oriented studies 1(1), i-xiv.

Chapman, H., 2003: Global warming. The implications for sustainable archaeological resource management, Conservation and management of archaeological sites 5(4), 241-45.

Clark, N., and M.J. Hird, 2014: 'Deep shit', O-zone. A journal of object-oriented studies 1(1), 44-52.

Clarke, B., 2014: 'The Anthropocene,' or, Gaia shrugs, Journal of contemporary archaeology 1(1), 101-4.

Coe, J.M., and D. Rogers, 1997: Marine debris. Sources, impacts, and solutions, New York.

Colette, A. (ed.), 2007: Climate change and world heritage. Report on predicting and managing the impacts of climate change on world heritage and strategy to assist states parties to implement appropriate management responses, Paris.

Corcoran, P.L., C.J. Moore and K. Jazvac, 2014: An anthropogenic marker horizon in the future rock record, GSA today 24(6), 4-8.

Crossland, Z., 2014: Anthropocene. Locating agency, imagining the future, Journal of contemporary archaeology 1(1), 123-28.

Crumley, C., 2015: New paths into the Anthropocene. Applying historical ecologies to the human future, in C. Isendahl and D. Stump (eds), The Oxford handbook of historical ecology and applied archaeology, Oxford, 1-13.

Crutzen, P.J., 2002: Geology of mankind, Nature 415, 23.

Crutzen, P.J., and E.F. Stoermer, 2000: The Anthropocene, Global change newsletter 41, 17-18.

Dalby, S., 2016: Framing the Anthropocene. The good, the bad and the ugly, Anthropocene review 3(1), 33-51.

Davies, M.I.J., and F.N. M'Mbogori (eds), 2013: Humans and the environment. New archaeological perspectives for the 21st century, Oxford.

DeLanda, M., 2006: A new philosophy of society. Assemblage theory and social complexity, London.

Douglas, M., 1966: Purity and danger. An analysis of the concepts of pollution and taboo, London.

Edgeworth, M., 2013: The relationship between archaeological stratigraphy and artificial ground and its significance in the Anthropocene, in C. Waters, J.A. Zalasiewicz, M. Williams, M.A. Ellis and A.M. Snelling (eds), A stratigraphic basis for the Anthropocene, London (Geological Society Special Publications 395(1)), 91-108.

Edgeworth, M., 2014: Introduction, Journal of contemporary archaeology 1(1), 73-77.

Edgeworth, M., 2016a: Grounded objects. Archaeology and speculative realism, Archaeological dialogues 23(1), 93-113.

Edgeworth, M., 2016b. Humans. Part of dynamic assemblages (of species, niches, forces) that are changing Earth (the Evolution Institute), available at https://evolution-institute.org/commentary/humans-part-of-dynamicassemblages-of-species-niches-forces-that-are-changing-earth. 
Edgeworth, M., et al., 2014: Forum. Archaeology of the Anthropocene, Journal of contemporary archaeology 1(1), 73-132.

Edgeworth, M., D. deB. Richter, C. Waters, P. Haff, C. Neal and S.J. Price, 2015: Diachronous beginnings of the Anthropocene. The lower bounding surface of anthropogenic deposits, Anthropocene review 2(1), 33-58.

Ellis, E., 2012: The planet of no return. Human resilience on an artificial earth, The breakthrough, at http://thebreakthrough.org/index.php/journal/ past-issues/issue-2/the-planet-of-no-return.

Eriksen, M., et al., 2014: Plastic pollution in the world's oceans. More than 5 trillion plastic pieces weighing 250,000 tons afloat at sea, PLoS ONE 9(12), available at https://doi.org/10.1371/journal.pone.0111913.

Erlandson, J.M., and Braje, T.J., 2013: Archeology and the Anthropocene, Anthropocene 4, 1-7.

Galgani, F., G. Hanke and T. Maes, 2015: Global distribution, composition and abundance of marine litter, in M. Bergmann, L. Gutow and M. Klages (eds), Marine anthropogenic litter, Bremerhaven and Gothenburg, 29-56.

Galloway, T.S., 2015: Micro- and nano-plastics and human health, in M. Bergmann, L. Gutow and M. Klages (eds), Marine anthropogenic litter, Bremerhaven and Gothenburg, 343-66.

Gibbard, P.L., and M.J.C. Walker, 2013: The term 'Anthropocene' in the context of formal geological classifications, in C. Waters, J.A. Zalasiewicz, M. Williams, M.A. Ellis and A.M. Snelling (eds), A stratigraphic basis for the Anthropocene, London (Geological Society Special Publications 395(1)), 29-37.

Ginzburg, C., 1980: Morelli, Freud and Sherlock Holmes. Clues and scientific method, History workshop 9, 5-36.

González-Ruibal, A., 2011: Naturalizing the Anthropocene? Ideology, heritage and modernity, Norwegian archaeological review 44(1), 62-64.

Gosden, C., and Y. Marshall, 1999: The cultural biography of objects, World archaeology 31(2), 169-78.

Guttmann-Bond, E., 2010: Sustainability out of the past. How archaeology can save the planet, World archaeology 42(3), 355-66.

Haraway, D., 2016: Staying with the trouble. Making kin in the Chthulucene, Durham, NC.

Harman, G., 2010: Towards speculative realism. Essays and lectures, Winchester. Harman, G., 2016: Immaterialism, Cambridge.

Harrison, R., 2015: Beyond 'natural' and 'cultural' heritage. Toward an ontological politics of heritage in the age of Anthropocene, Heritage \& society $8(1), 24-42$.

Hodder, I., 2014: The entanglements of humans and things. A long-term view, New literary history 45(1), 19-36.

Holtorf, C., 2002: Notes on the life history of a pot sherd, Journal of material culture 7(1), 49-72.

Hoskins, J., 1998: Biographical objects. How things tell the stories of people's lives, New York.

Howard, A.J., 2013: Managing global heritage in the face of future climate change. The importance of understanding geological and geomorphological processes and hazards, International journal of heritage studies 19(7), 632-58.

Howard, A.J., K. Challis, J. Holden, M. Kincey and D.G. Passmore, 2005: The impact of climate change on archaeological resources in Britain. A catchment scale assessment, Climatic change 91(3), 405-22. 
Hudson, M.J., 2014: Dark artifacts. Hyperobjects and the archaeology of the Anthropocene, Journal of contemporary archaeology 1(1), 8286.

Hudson, M.J., M. Aoyama, K.C. Hoover and J. Uchiyama, 2012: Prospects and challenges for an archaeology of global climate change, WIREs climate change 3, 313-28.

Ingold, T., 2007: Materials against materiality, Archaeological dialogues 14(1), $1-16$.

Kaslegard, A.S., (ed.), 2010: Climate change and cultural heritage in the Nordic countries, Copenhagen.

Kintigh, K.W., J.H. Altschul, M.C. Beaudry, R.D. Drennan et al., 2014: Forum. Grand challenges for archaeology, American antiquity 79(1), 5-24.

Kluiving, S.J., and Hamel, A., 2016: How can archaeology help us unravel the Anthropocene?, in M.W. Ertsen, C. Mauch and E. Russell (eds), Molding the planet. Human niche construction at work, Munich (RCC Perspectives. Transformations in Environment and Society 5), 55-62.

Kolbert, E., 2014: The sixth extinction. An unnatural history, New York.

Kopytoff, I., 1986: The cultural biography of things. Commoditization as process, in A. Appadurai (ed.), The social life of things. Commodities in cultural perspective, Cambridge, 64-91

Kristjánsson, L., 1980: Íslenzkir sjávarhœettir I, Reykjavík.

Lafrenz Samuels, K., 2016: The cadence of climate. Heritage proxies and social change, Journal of social archaeology 16(2), 142-63.

Lane, P.J., 2015: Archaeology in the age of the Anthropocene. A critical assessment of its scope and societal contributions, Journal of field archaeology 40(5), 1-14.

Latour, B., 2011: Love your monsters. Why we must care for our technologies as we do our children, Breakthrough journal 2, 21-28.

Latour, B., 2014: Agency at the time of the Anthropocene, New literary history 45, 1-18.

LeCain, T.J., 2015: Against the Anthropocene. A neo-materialist perspective, International journal for history, culture and modernity 3(1), 1-28.

Liboiron, M., 2016: Redefining pollution and action. The matter of plastics. Journal of material culture 21(1), 87-110.

Lucas, G., 2011: Constructivism and the Mechanocene, Norwegian archaeological review 44(1), 66-68.

Lucas, G., 2012: Understanding the archaeological record, New York.

Lucas, G., 2015: Archaeology and contemporaneity, Archaeological dialogues 22(1), 1-15.

Lucas, G., Z. Crossland, A.M. Jones, H. Karlsson, L. Olivier and T. Yarrow et al., 2015: Archaeology and contemporaneity, Archaeological dialogues 22(1), $1-44$.

Lusher, A., 2015: Microplastics in the environment. Distribution, interactions and effects, in M. Bergmann, L. Gutow and M. Klages (eds), Marine anthropogenic litter, Bremerhaven and Gothenburg, 245-307.

Macfarlane, R., 2016: Generation Anthropocene. How humans have altered the planet for ever, The Guardian, 1 April, available at www.theguardian.com/ books/2016/apr/01/generation-anthropocene-altered-planet-for-ever.

Malpas, J., 2012: Heidegger and the thinking of place. Explorations in the topology of being, Cambridge, MA. 
Margulis, L., 1995: Gaia is a tough bitch, in J. Brockman (ed.), The third culture. Beyond the scientific revolution, New York, 129-51.

Mitchell, P., 2008: Practicing archaeology at a time of climatic catastrophe, Antiquity 82, 1093-1103.

Morton, T., 2007: Ecology without nature. Rethinking environmental aesthetics, Cambridge, MA.

Morton, T., 2010: The ecological thought, Cambridge, MA.

Morton, T., 2013: Hyperobjects. Philosophy and ecology after the end of the world, Minneapolis.

Morton, T., 2016: Dark ecology. For a logic of future coexistence, New York.

Nativ, A., 2014: Anthropocentricity and the archaeological record. Towards a sociology of things, Norwegian archaeological review 47(2), 180-95.

Olsen, B., 2010: In defense of things. Archaeology and the ontology of objects, Lanham, MD.

Olsen, B., 2012: After interpretation. Remembering archaeology, Current Swedish archaeology 20, 11-34.

Olsen, B., 2013: Reclaiming things. An archaeology of matter, in P.L. Carlile, D. Nicolini, A. Langley and H. Tsoukas (eds), How matter matters. Objects, artifacts and materiality in organization studies, Oxford, 171-96.

Olsen, B., M. Shanks, T. Webmoor and C. Witmore, 2012: Archaeology. The discipline of things, Berkeley, CA.

Periman, R.D., 2006: Visualizing the Anthropocene. Human land use history and environmental management, in C. Aguirre-Bravo, P.J. Pellicane, D.P. Burns and S. Draggan (eds), Monitoring science and technology symposium. Unifying knowledge for sustainability in the western hemisphere, proceedings, Fort Collins, CO, 558-64, available at www.treesearch.fs.fed.us/pubs/26486.

Pétursdóttir, P., 2012: Small things forgotten now included, or what else do things deserve?, International journal of historical archaeology 16(3), 577-603.

Pétursdóttir, P., 2014: Things out-of-hand. The aesthetics of abandonment, in B. Olsen and P. Pétursdóttir (eds), Ruin memories. Materiality, aesthetics and the archaeology of the recent past, London, 335-64.

Pétursdóttir, P., forthcoming: Drift, in S.E. Pilaar Birch (ed.), Multispecies archaeology, London.

Pham, C.K., E. Ramirez-Llodra, C.H.S. Alt, T. Amaro et al., 2014: Marine litter distribution and density in European seas, from the shelves to deep basins, PLOS ONE 9, available at http://journals.plos.org/plosone/article?id= 10.1371/journal.pone.0095839.

Ramirez-Llodra, E., P.A. Tyler, M.C. Baker, O.A. Bergstad et al., 2011: Man and the last great wilderness. Human impact on the deep sea, Plos One 6(7), 1-25.

Randall, A., 2016: Time, agency and the Anthropocene, Antiquity 90(350), 51617.

Rockman, M., 2012: The necessary roles of archaeology in climate change mitigation and adaptation, in M. Rockman and J. Flatman (eds), Archaeology in society. Its relevance in the modern world, London, 193-215.

Ruddiman, W.F., 2003: The anthropogenic greenhouse era began thousands of years ago, Climatic change 61, 261-93.

Ruddiman, W.F., 2005: Plows, plagues and petroleum. How humans took control of climate, Princeton, NJ. 
Rull, V., 2013: A futurist perspective on the Anthropocene, The Holocene 23(8), 1198-1201.

Ryan, P.G., 2015: A brief history of marine litter research, in M. Bergmann, L. Gutow and M. Klages (eds), Marine anthropogenic litter, Bremerhaven and Gothenburg, 1-25.

Sabbioni, C., P. Brimblecombe and M. Cassar (eds), 2010: The atlas of climate change impact on European cultural heritage. Scientific analysis and management strategies, London.

Sandweiss, D.H., and A.R. Kelley, 2012: Archaeological contributions to climate change research. The archaeological record as a paleoenvironmental archive, Annual review of anthropology 41, 371-91.

Solli, B., et al., 2011: Some reflections on heritage and archaeology in the Anthropocene, Norwegian archaeological review 44(1), 40-88.

Steffen, W., J. Grinevald, P. Crutzen and J. McNeil, 2011: The Anthropocene. Conceptual and historical perspectives, Philosophical transactions of the Royal Society A 369, 842-67.

Sullivan, H.I., 2012: Dirt theory and material ecocriticism, Interdisciplinary studies in literature and environment 19(3), 515-31.

Sørensen, T.F., 2016: In praise of vagueness. Uncertainty, ambiguity and archaeological methodology, Journal of archaeological method and theory 23(2), 741-63.

Terrill, G., 2008: Climate change. How should the world heritage convention respond?, International journal of heritage studies 14(5), 388-404.

Thompson, R.C., 2006: Plastic debris in the marine environment. Consequences and solutions, in J.C. Krause, H. Nordheim and S. Bräger (eds), Marine nature conservation in Europe, Stralsund, 107-15.

Thompson, R.C., 2015: Microplastics in the marine environment. Sources, consequences and solutions, in M. Bergmann, L. Gutow and M. Klages (eds), Marine anthropogenic litter, Bremerhaven and Gothenburg, 185-200.

UNEP, 2009: Marine litter. A global challenge (ed N. Meith), Nairobi.

van de Noort, R., 2011: Conceptualising climate change archaeology, Antiquity 85, 1039-48.

Wark, M., 2015: Molecular red. Theory for the Anthropocene, London.

Woodall, L.C., A. Sanchez-Vidal, M. Canals, G.L.J. Paterson et al., 2014: The deep sea is a major sink for microplastic debris, Royal Society open science 1, available at http://rsos.royalsocietypublishing.org/content/1/4/140317.

Yusoff, K., 2016: Anthropogenesis. Origins and endings in the Anthropocene, Theory, culture \& society 33(2), 3-28.

Zalasiewicz, J., C.N. Waters, J.A. Ivar do Sul, P.L. Corcoran et al., 2016: The geological cycle of plastics and their use as a stratigraphic indicator of the Anthropocene, Anthropocene 13, 4-17, available at www.sciencedirect. com/science/article/pii/S2213305416300029.

Zalasiewicz, J., M. Williams, A. Haywood and M. Ellis, 2011: The Anthropocene. A new epoch of geological time?, Philosophical transactions of the Royal Society A 369, 835-41.

Zerzan, J., 2012: The sea, Anagnori, available at https://anagnori.wordpress. com/2012/09/08/featured-essay-the-sea-by-john-zerzan, accessed 24 May 2014. 